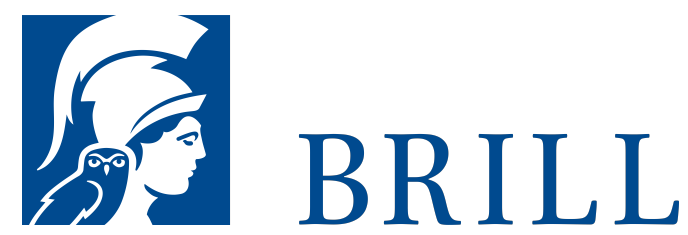

\title{
Verbotene Früchte
}

Wie viel Ökonomie verträgt die Organspende?

Author:Jan-Ole Reichardt

Die Liste der Patienten, die auf eine gespendete Leber oder Niere warten, ist lang und wird täglich länger. Das Problem: Solange nicht genügend Organe von Verstorbenen verfügbar sind, müssten sich mehr Menschen zu einer Lebendspende bereit erklären. Doch wer legt sich schon freiwillig für Fremde unters Messer? Um hierfür mehr Anreize zu schaffen, wird in den USA über eine Entlohnung der Spender nachgedacht. Davon verspricht man sich auch den bereits existierenden Schwarzmarkt einzudämmen. Nur: Ist es moralisch vertretbar, Organspender zu bezahlen? Der deutsche Gesetzgeber hat diese Frage strikt verneint. In diesem Buch unterzieht Jan-Ole Reichardt das spenderseitige Gewinnverbot einer moralphilosophischen Analyse. Am Beispiel dieser hochaktuellen Frage wird zugleich demonstriert, auf welche Weise die Ethik zur Klärung moralischer Streitfragen der Gegenwart beitragen kann und muss. Ein weit über die Medizinethik hinausweisendes Projekt zu den Fundamenten unseres menschlichen Miteinanders.

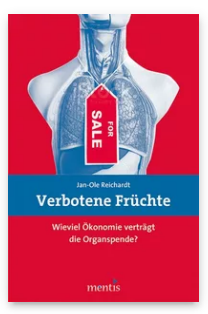

Pages: 348

Seiten

Language:

German

Subjects:

General,

Philosophy

Publisher: Brill | mentis

E-Book (PDF)

Released online:

o1 Mar 2016

ISBN: 978-3-

95743-909-3

List price

Paperback

Publication date:

15 Feb 2016

ISBN: 978-3-

95743-019-9

List price 
For more information see brill.com

Order information: Order online at brill.com +44330 333 0049 | customerservices@brill.com Submission information: brill.com/authors

Titles published by Brill | Fink, Brill | mentis or Brill | Schöningh: +49(o)715413279216| brill@brocom.de 